\title{
PANCASILA SEBAGAI PANDANGAN HIDUP BANGSA
}

D
$\mathrm{I}$
$\mathrm{S}$
$\mathrm{U}$
$\mathrm{S}$
$\mathrm{U}$
$\mathrm{N}$
OLEH
KELOMPOK 1:

1. Billyman Laoli (ketua)

6. Kristin Gulo

2. Arta Nurcahaya

7. Susi Santuri

3. Ayu Sundari

8. Sylvia Sianturi

4. Cindy Pangaribuan

9. Yosi Sihotang

5. Friska Situmorang

Dosen Pembimbing : Krista Surbakti, S.pd, M.Si

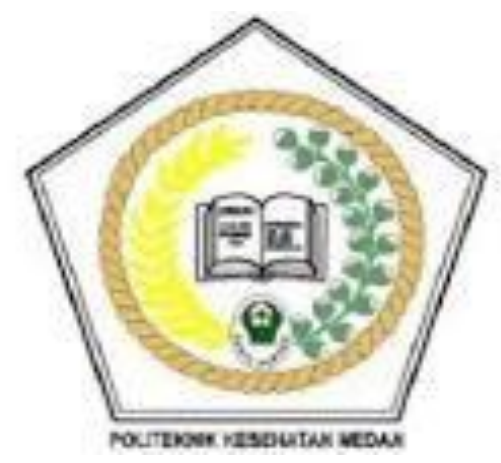

POLTEKKES KEMENKES MEDAN

JURUSAN KEPERAWATAN

T.A 2019/2020 


\section{KATA PENGANTAR}

Puji syukur penulis panjatkan kehadirat Allah SWT bahwa dengan Rahmat dan RidhoNya penulis dapat menyelesaikan Makalah Pendidikan Pancasila yang berjudul "Pancasila Sebagai Pandangan Hidup Bangsa Indonesia"

Adapun isi dari Makalah ini adalah Pancasila Sebagai Pandangan Hidup Bangsa Indonesia, Penjabaran Nilai - Nilai Pancasila, Upaya Menjaga Nilai - Nilai Luhur Pancasila.

Semoga Makalah ini dapat menambah wawasan kita semua dan dapat memenuhi kriteria tugas yang bapak berikan serta dapat menjadi nilai tambah untuk penulis.

Tak ada yang sempurna, begitu pula dengan penulisan makalah ini. Oleh sebab itu penulis menerima kritik positif dari pembaca sebagai perbaikan bagi penulis dimasa yang akan datang. Semoga makalah ini bermanfat.

Akhir kata penulis ucapkan "Terima Kasih" 


\section{DAFTAR ISI}

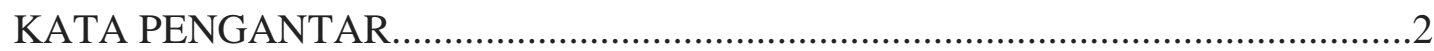

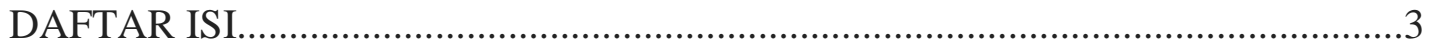

\section{BAB I PENDAHULUAN}

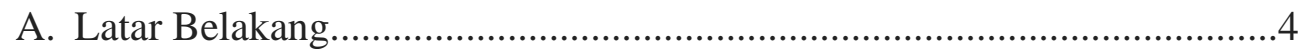

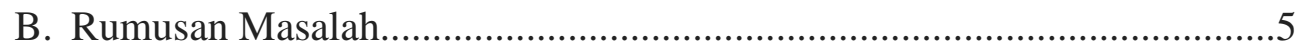
C. Tujuan Penulisan..............................................................................

BAB II PEMBAHASAN
A. Pancasila Sebagai Pandangan Hidup Bangsa Indonesia.........................6
B. Penjabaran Nilai - Nilai Pancasila.........................................................8
C. Upaya Menjaga Nilai - Nilai Luhur Pancasila......................................13

\section{BAB III PENUTUP}
A. Saran...
.14
B. Kesimpulan. 


\section{BAB I}

\section{PENDAHULUAN}

\section{Latar Belakang}

Pancasila selain sebagai dasar Negara, juga merupakan pandangan hidup bangsa Indonesia. Sejarah telah mengungkapkan bahwa pancasila adalah jiwa dari seluruh bangsa Indonesia yang mampu memberi kekuatan hidup kepada bangsa Indonesia serta membimbingnya dalam mengejar kehidupan lahir batin yang makin baik, di dalam masyarakat Indonesia yang adil dan makmur.

Pancasila yang diterima dan ditetapkan sabagai dasar Negara seperti yang tercantum dalam pembukaan UUD 1945 merupakan kepribadian dan pandangan hidup bangsa. Pembelajaran pancasila menjadi sangat penting, karena mengingat pancasila merupakan jiwa dari seluruh rakyat Indonesia. Hal ini mengandung makna bahwa di dalam pancasila mengandung jiwa yang luhur, nilai-nilai yang luhur dan sarat dengan ajaran moralitas.

Kadang kala nilai-nilai luhur yang ada dalam pancasila yang merupakan penjelmaan dari seluruh bangsa Indonesia tidak dipraktekan dalam kehidupan sehari-hari, tetapi diabaikan sehingga akibat dari itu nilai-nila luhur tersebut dengan sendirinya akan hilang. Menyadari bahwa untuk kelestarian nilai-nilai pancasila itu perlu diusahakan secara nyata dan terus-menerus pengahayatan dan pengamalan nila-nilai luhur yang terkandung di dalamnya, oleh sebab itu setiap warga Negara Indonesia, penyelenggara Negara, serta lembaga kenegaraan dan lembaga kemasyarakatan baik di pusat maupun di daerah harus sama-sama mengamalkan nilai-nilai pancasila demi kelestarianya. 


\section{B. Rumusan Masalah}

Berdasarkan uraian dalam latar belakang, maka penulis merumuskan masalah-masalah yang akan di bahas diantaranya:

1. Bagaimana hakikat Pancasila sebagai pandangan hidup bangsa?

2. Bagaimana penjabaran tiap-tiap sila dari Pancasila?

3. Apa saja upaya - upaya dalam menjaga nilai - nilai luhur pancasila?

\section{Tujuan Penulisan}

Penulisan Dalam penyusunan Makalah ini, penulis mempunyai beberapa tujuan, yaitu:

1. Untuk mengetahui hakikat Pancasila sebagai pandangan hidup bangsa

2. Untuk mengetahui penjabaran tiap-tiap sila dari Pancasila

3. Untuk mengetahui upaya - upaya dalam menjaga nilai - nilai luhur pancasila 


\section{BAB II \\ PEMBAHASAN}

\section{A. Pancasila Sebagai Pandangan Hidup Bangsa Indonesia}

\section{Arti Pandangan Hidup Suatu Bangsa}

Sejak tanggal 28 Oktober 1928 kita telah menjadi satu bangsa, artinya satu kesatuan dari berbagai ragam latar belakang sosial budaya, agama dan keturunan yang bertekad untuk membangun satu tatanan hidup berbangsa dan bernegara.

Setiap bangsa mempunyasi cita-cita untuk masa depan dan menghadapi masalah bersama dalam mencapai cita-cita bersama. Cita-cita kita sebagai bangsa Indonesia tercantum dalam Pembukaan UUD 1945, yakni mewujudkan suatu tatanan masyarakat yang adil dan makmur materil dan spirituan berdasarkan Pancasila. Seperti halnya keluarga, suatu bangsa yang bertekad mencapai cita-cita bersama memerlukan suatu pandangan hidup. Tanpa pandangn hidup, suatu bangsa akan terombang ambing. Dengan pandangan hidup suatu bangsa dapat secara jelas mengetahui arah yang dicapai. Dengan pandangan hidup, suatu bangsa akan : dengan mudah memandang persoalan-pesoalan yang dihadapi; dengan mudah mencari pemecahan masalahmasalah yang dihadapi; memiliki pedoman dan pegangan; dan membangun dirinya.

Dengan uraian di atas jelaslah betapa pentingnya pandangan hidup suatu bangsa. Pertanyaan berikut yang secara wajar muncul pada diri kita sendiri " apakah pandangan hidup itu sesungguhnya?".

Pandangan hidup suatu bangsa adalah :

a. Cita-cita bangsa;

b. Pikiran-pikiran yang mendalam;

c. Gagasan mengenai wujud kehidupan yang lebih baik.

Jadi pandangan hidup suatu bangsa adalah inti sari (kristalisasi) dari nilai-nilai yang dimiliki bangsa itu dan diyakini kebenaranya, yang berdasarkan pengalaman sejarah dan yang telah menimbulkan tekad pada bangsa itu untuk mewujudkanya dalam kehidupan sehari-hari.

\section{Pandangan Hidup Bangsa Indonesia}

Dalam pandangan hidup terkandung konsep dasar mengenai kehidupan yang dicitacitakan oleh sesuatu bangsa, terkandung pikiran yang dianggap baik. Oleh karena itu pandangan hidup suatu bangsa merupakan masalah yang sangat asasi bagi kekokohan dan kelestarian suatu bangsa. Negara Republik Indonesia memang tergolong muda dalam barisan Negara-negara lain 
di dunia. Tetapi bangsa Indonesia lahir dari sejarah dan kebudayaan yang tua, melalui gemilangnya Kerajaan Sriwijaya, Majapahit dan Mataram. Kemudian mengalami penderitaan penjajahan sepanjang tiga setengah abad, sampai akhirnya bangsa Indonesia memproklamasikan kemerdekaanya pada tanggal 17 Agustus 1945. Sejarah perjuangan bangsa Indonesia untuk merebut kembali kemerdekaan nasionalnya sama tuanya dengan sejarah penjajahan itu sendiri.

Bangsa Indonesia lahir menurut cara dan jalan yang ditempuhnya sendiri yang merupakan hasil antara proses sejarah di masa lampau, tantangan perjuangan dan cita-cita hidup di masa yang akan datang, yang secara keseluruhan membentuk kepribadianya sendiri. Oleh karena itu bangsa Indonesia lahir dengan kepribadianya sendiri, yang bersamaan dengan lahirnya bangsa dan Negara itu, kepribadian itu ditekankan sebagai pandangan hidup dan dasar Negara Pancasila. Bangsa Indonesia lahir dengan kekuatan sendiri, maka percaya pada diri sendiri juga merupakan salah satu ciri kepribadian bangsa Indonesia. Kare \na itulah, Pancasila bukan lahir secara mendadak pada tahun 1945, melainkan telah melalui proses yang panjang, dimatangkan oleh sejarah perjungan bangsa kita sendiri, dengan melihat pengalaman bangsa-bangsa lain, dengan diilhami oleh bangsa kita dan gagasan-gagasan besar bangsa kita sendiri.

Karena pancasila sudah merupakan pandangan hidup yang berakar dalam kepribadian bangsa, maka ia diterima sebagai Dasar Negara yang mengatur hidup ketatanegaraan. Hal ini tampak dalam sejarah bahwa meskipun dituangkan dalam rumusan yang agak berbeda, namun dalam tiga buah UUD yang pernah kita miliki yaitu dalam pembukaan UUD 1945, Mukadimah Konstitusi Republik Indonesia Serikat dan UUD sementara Republik Indonesia tahun 1950 pancasila itu tetap tercantum di dalamnya.

Pancasila yang selalu dikukuhkan dalam kehidupan konstitusional kita, Pancasila selalu menjadi pegangan bersama pada saat terjadi krisis nasional dan ancaman terhadap eksistensi bangsa kita, merupakan bukti sejarah bahwa Pancasila memang selalu dikehendaki oleh bangsa Indonesia sebagai dasar kerohanian bangsa, dikehendaki sebagai Dasar Negara.

\section{Pancasila Sebagai Pandangan Hidup Bangsa}

M\anusia yang diciptakan oleh Tuhan yang Maha Kuasa, dikodratkan hidup secara berkelompok. Kelompok manusia itu akan selalu mengalami perubahan dan perkembangan. Perkembangan manusia dari yang mengelompok sampai pada suatu keadaan dimana mereka itu terjalin ikatan hubungan yang kuat dan serasi. Ini adalah pertanda adanya kelompok manusia dengan ciri-ciri kelompok tertentu, yang membedakan mereka dengan kelompok- 
kelompok manusia lainya. Kelopmok ini membesar dan menjadi suku-suku bangsa. Tiap suku bangsa dibedakan oleh perbedaan nilai-nilai dan moral yang mereka patuhi bersama. Berdasarkan hal ini kita dapat menyebutkan adanya kelompok suku bangsa Minangkabau, Batak, Jawa, Flores, Sunda, Madura, dan lain sebagainya. Semua suku itu adalah modal dasar terbentuknya kesadaran berbangsa dan adanya bangsa Indonesia yang kita miliki adalah bagian dari bangsa itu sekarang ini.

Kelompok-kelompok manusia tersebut dikatakan suku bangsa, karena mempunyai tujuan hidup. Tujuan hidup kelompok ini akan membedakan mereka dengan kelompok suku bangsa lain di Nusantara. Jadi kita kenal dengan pandangan hidup suku Jawa, Sunda, Batak, Flores, Madura, dan lain-lain sebagainya.

Pandangan hidup merupakan wawasan atau cara pandang mereka untuk memenuhi kehidupan di dunia dan bekal di hari akhir. Bangsa Indonesia yang terdiri dari suku bangsa tersebut, meyakini adanya kehidupan di dunia dan hari akhir. Berdasarkan hal tersebut kita menemukan persamaan pandangan hidup di antara suku-suku bangsa di tanah air ini, ialah keyakinan mereka adanya dua dunia kehidupan.

Inilah yang menyatukan pandangan hidup bangsa Indonesia, walaupun mereka terdiri atas berbagai suku yang berbeda. Bangsa Indonesia yang terikat oleh keyakinan Kepada Tuhan yang Maha Kuasa dan kuatnya tradisi sebagai norma dan nilai kehidupan dalam masyarakat adalah tali persamaan pandangan hidup antara berbagai suku bangsa di Nusantara ini. Pandangan hidup kita berbangsa dan bernegara tersimpul dalam falsafah kita Pancasila.

Pancasila memberikan pancaran dan arah untuk setiap orang Indonesia tentang masa depan yang ditempuhnya. Inilah pandangan hidup bangsa Indonesia sebagaimana tertuang dalam kelima Sila Pancasila.

\section{B. Penjabaran Nilai - Nilai Pancasila}

\section{Sila Ketuhanan Yang Maha Esa}

Dengan adanya dasar Ketuhanan maka Indonesia mengakui dan percaya pada adanya Tuhan. Tuhan Yang Maha Esa, yang menjadi sebab adanya manusia dan alam semesta serta segala hidup dan kehidupan di dalamnya.

Dasar ini menjamin kemerdekaan tiap-tiap penduduk Indonesia untuk memeluk agamanya/kepercayaanya, sebagaimana tercantum dalam pasal 29 UUD 1945. Hal ini berarti bahwa, Negara Indonesia yang terdiri atas beribu-ribu pulau dengan lebih kurang 200 lebih juta 
penduduk yang menganut beberapa agama, menghendaki semua itu hidup tentram, rukun dan saling menghormati.Denga demikian semua agama diakui di Negara Republik Indonesia, dapat bergerak dan berkembang secara leluasa.

Sila pertama pancasila berbunyi "Ketuhanan Yang Maha Esa" terdiri dari dua pengertian pokok yaitu pengertian tentang Ketuhanan dan tentang Yang Maha Esa.

\section{- Ketuhanan}

Ketuhanan berasal dari kata Tuhan yakni Allah, zat Yang Maha Esa, pencipta segala kejadian termasuk pencipta semua makhluk. Oleh karena itu Tuhan sering disebut juga "sebab yang pertama" yang tidak disebabkan lagi. Alam beserta kekayaanya seperti sumber-sumber minyak bumi, batubara, air dan lain-lainya merupakan ciptaanya. Demikian dengan makhluk hidup merupakan cipataan Tuhan juga.

\section{- $\quad$ Yang Maha Esa}

Yang maha Esa berarti yang maha satu atau maha tunggal dan tidak ada yang mempersekutukan-Nya. Dia esa dalam zat-Nya, esa dalam sifat-Nya, esa dalam perbuatan-Nya. Oleh kaena adanya kekhususanya itu, maka tidak ada yang menyamainya dan Dia maha sempurna.

Sila Ketuhanan Yang Maha Esa mengandung pengertian bahwa kita bangsa Indonesia percaya dan takwa kepada Tuhan Yang Maha Esa, pencipta alam semesta beserta isinya, baik benda mati maupun makhluk hidup.

\section{Sila Kemanusiaan Yang Adil dan Beradab}

Internasionalisme ataupun peri kemanusiaan adalah penting sekali bagi kehidupan sesuatu bangsa dalam Negara yang merdeka dalam hubunganya dengan bangsa-bangsa lain. Manusia adalah makhluk Tuhan, dan Tuhan tidak mengadakan perbedaan antara sesama manusia. Pandangan demikian menimbulkan pandangan yang luas, tidak terikat oleh batas-batas Negara atau bangsa sendiri, melainkan Negara harus selalu membuka pintu bagi persahabatan dunia atas dasar persamaan derajat.

Manusia mempunyai hak-hak yang sama, oleh karena itu tidaklah dibenarkan manusia yang satu menguasai manusia yang lain, atau bangsa yang satu menguasai bangsa yang lain. Berhubung dengan hal itu maka tidak membenarkan adanya penjajahan di atas bumi, karena hal yang demikian bertentangan dengan peri kemanusiaan serta hak setiap bangsa menentukan nasibnya sendiri. Sesungguhnhya manusia itu dilahirkan mempunyai hak yang tidak dapat 
dirampas dan dihilangkan. Hak-hak itu harus dihormati oleh siapapun. Golongan manusia yang berkuasa tidaklah diperkenankan memaksakan kehendaknya yang bertentangan dengan hak seseorang.

Sila Kemanusiaan Yang Adil Dan beradab mengandung beberapa pengertian pokok diantarnya:

\section{- Kemanusiaan}

Kemanusiaan berasal dari kata amnesia, uang merupakan makhluk ciptaan tuhan Yang Maha Esa. Oleh Tuhan manusia di karunia jasmani dan rohani, yang keduanya merupakan satu kesatuan serasi, yang sering disebut pribadi manusia.

\section{- $\quad$ Adil}

Adil mengandung arti obyektif atau sesuai dengan adanya, misalnya kita memberikan sesuatu kepada orang lain, karena memang sesuatu itu merupakan haknya. Jadi, kita tidak subyektif, tidak berat sebelah, tidak pilih kasih.

\section{- Beradab}

Beradab berasal dari kata adab yang secara bebas berearti budaya. Dengan demikian beradab berarti berbudaya. Manusia yang beradab berarti manusia yang tingkah lakunya selalu dijiwai oleh nilai-nilai kebudayaan. Niali-niali budaya tidak lain ialah hal-hal yang luhur, yang dijunjung tinggi oleh manusia, yang karena luhurnya itu dijadikan pedoman, ukuran, atau tuntunan untuk diikuti. Kalau sesuai berarti baik, kalau tidak sesuai berarti tidak baik.

\section{Sila Persatuan Indonesia}

Dengan dasar kebangsaan (nasionalisme) dimaksudkan bahwa bangsa Indonesia seluruhnya harus memupuk persatuan yang erat antara sesama warga, tanpa membeda-bedakan suku atau golongan serta berdasarkan satu tekad yang bulat dan satu cita-cita bersama. Prinsip kebangsaan itu merupakan ikatan yang erat antara golongan dan suku bangsa.

Paham kebangsaan kita adalah satu dasar kebangsaan yang menuju kepada persaudaraan dunia, yang menghendaki bangsa-bangsa itu saling hormat-menghormati dan harga-menghargai. Paham kebangsaan yang dianut oleh bangsa Indonesia adalah:

a. Ke dalam, menggalang seluruh kepentingan rakyat dengan tidak membedakan suku atau golongan. 
b. Ke luar; tidak mengagungkan bangsa sendiri, namun dengan berdiri tegak atas dasar kebangsaan sendiri juga menuju kea rah hidup berdampingan secara damai, berdasar atas persamaan derajat antar bangsa serta berdaya upaya untuk melaksanakan terciptanya perdamaian dunia yang kekal; dan abadi, serta membina kerja sama untuk kesejahteraan umat manusia. Sila Persatuan Indonesia mengandung beberapa pengertian di antaranya:

\section{Persatuan}

Persatuan berasal dari kata satu yang berarti utuh, tidak pecah belah, persatuan mengandung pengertian disatukanya berbagai macam corak yang beraneka ragam menjadi satu kebulatan. Dengan perkataan lain, hal-hal yang beraneka ragam itu setelah disatukan menjadi sesuatu hal yang serasi, utuh dan tidak saling bertentangan antar yang satu dengan yang lain.

\section{Indonesia}

Yang dimaksud dengan Indonesia ialah dalam pengertian geografis dan bangsa yang mendiami wilayah Indonesia.

\section{Sila Kerakyatan Yang Dipimpin Oleh Hikmat Kebijaksanaan Dalam Permusyawaratan/Perwakilan}

Dasar mufakat, kerakyatan atau demokrasi menunjukan bahwa Negara Indonesia menganut paham demokrasi. Paham demokrasi berarti bahwa kekuasaan tertinggi (kedaulatan) untuk mengatur Negara dan rakyat terletak di tangan seluruh rakyat. Dalam UUD 1945 menyatakan bahwa "kedaulatan adalah di tangan rakyat dan dilakukan sepenuhnya oleh Majelis Permusyawaratan Perwakilan". Demokrasi Indonesia seperti yang tercantum dalam Pembukaan UUD 1945 adalah demokrasi yang tercantum dalam pancasila sebagai sila ke empat dan dinamakan demokrasi pancasila. Asas demokrasi di Indonesia ialah demokrasi berdasarkan pancasila yang meliputi bidang-bidang politik, sosial dan ekonomi, serta yang dalam penyelesaian masalah-masalah nasional berusaha sejauh mungkin menmpuh jalan permusyawaratan untuk mencapai mufakat.

Hakikat dari musyawarah untuk mufakat dalam kemurnianya adalah suatu tata cara khas yang bersumber pada inti paham kerakyatan yang dipimpin oleh hikmat kebijaksaan dalam permusywaratan/ perwakilan untuk merumuskan dan atau memutuskan sesuatu hal berdasrkan kehendak rakyat, dengan jalan mengemukakan hikmat kebijaksanaan yang tiada lain dari pada pikiran (rasio) yang sehat yang mengungkapkan dan mempertimbangkan persatuan dan kesatuan bangsa, kepentingan rakyat sebagaimana yang menjadi tujuan pemebentukan pemerintah Negara 
termaksud dalam alinea ke empat Pembukaan UUD 1945. Oleh semua wakil/utusan yang mencerminkan penjelmaan seluruh rakyat, untuk mencapai keputusan berdasarkan kebulatan pendapat yang diitikadkan untuk dilaksanakan secara jujur dan bertanggung jawab. Keputusan berdasrakan mufakat adalah sah apabila diambil dalam rapat yang dihadiri oleh lebih dari separuh anggota yang hadir.

Sila Kerakyatan Yang Dipimpin Oleh Hikmat Kebijaksanaan Dalam Permusyawaratn/Perwakilan mengandung beberapa pengertian diantaranya:

\section{Kerakyatan}

Kerakyatan berasal dari kata rakyat yang berarti sekelompok manusia yang mendiami suatu wilayah tertentu. Kerakyatan berarti suatu prinsip yang mengakui bahwa kekuasaan tertinggi berada di tangan rakyat. Kerakyatan disebut juga kedaulatan rakyat, artinya rakyat yang berdaulat, berkuasa. Hal ini disebut juga demokrasi yang berarti rakyat yang memerintah.

\section{Hikmat Kebijaksanaan}

Hikmat Kebijaksanaan berarti suatu sikap yang dilandasi dengan penggunaan pikiran yang sehat dengan selalu mempertimbangkan persatuan dan kesataun bangsa. Kepentingan rakyat akan dijamin dengan sadar, jujur dan bertanggung jawab serta didorong oleh iktikad baik sesuai dengan hati nurani yang murni.

\section{Permusyawaratan}

Permusyawaratan berarti suatu tata cara yang khas Indonesia untuk merumuskan dan atau memutuskan sesuatu hal berdasarkan kehendak rakyat sehingga tercapai keputusan berdasarkan mufakat. Pelaksanaan dari kebenaran ini memerlukan semangat mengutamakan kepentingan nasional daripada kepentingan daerah, golongan dan pribadi. Hal ini memerlukan pula iktikd yang baik dan ikhlas, dilandasi oleh pikiran yang sehat serta ditopang oleh kesadaran bahwa kepentingan bangsa dan Negara mengalahkan kepentingan yang lain.

\section{Perwakilan}

Perwakilan berarti suatu tata cara untuk mengusahakan ikut sertanya rakyat mengambil bagian dalam urusan Negara. Bentuk keikutsertaan itu ialah badan-badan perwakilan, baik di pusat seperti MPR dan DPR maupun di daerah yang berwujud DPRD. Keanggotaan badan-badan perwakilan itu ditentukan melalui suatu pemilihan yang bersifat langsung, umum, bebas dan rahasia. 


\section{Sila Keadilan Sosial Bagi Seluruh Rakyat Indonesia}

Dalam pidato 1 Juni 1945 ditegaskan bahwa prinsip kesejahteraan adalah prinsip tidak adanya kemiskinan di alam Indonesia Merdeka. Keadilan sosial adalah sifat masyarakat adil dan makmur, kebahagiaan buat semua orang, tidak ada penghisapan, tidak ada penindasan, dan penghinaan, semuanya bahagia, cukup sandang dan pangan. Sila ini secara bulat berarti bahwa setiap rakyat Indonesia mendapat perlakuan yang adil dalam bidan hukum, politik, ekonomi, sosial budaya dan pertahanan keamanan. Sesuai dengan Undang-Undang Dasar 1945 pengertian keadilan mencakup pula pengertian adil dan makmur Sila Keadilan Sosial Bagi Seluruh Rakyat Indonesia mengandung beberapa pengertian diantaranya:

\section{Keadilan Sosial}

Keadilan sosial berarti keadilan yang berlaku dalam masyarakat di segala bidang kehidupan baik materil maupun spiritual. Hal ini berarti keadilan itu tidak hanya berlaku bagi orang yang kaya saja, tetapi berlaku pula bagi orang miskin, bukan hanya untuk para pejabat, tetapi untuk rakayta biasa pula.

\section{Seluruh Rakyat Indonesia}

Seluruh rakyat Indonesia berarti bahwa setiap orang yang menjadi rakyat Indonesia baik

yang berdiam di wilayah kekuasaan Republik Indonesia maupun warga Negara Indonesia yang berada di Negara lain.

\section{Upaya Menjaga Nilai - Nilai Luhur Pancasila}

Nilai - nilai yang terkandung dalam pancasila merupakan suatu cerminan dari kehidupan masyarakat Indonesia (nenek moyang kita) dan secara tetap telah menjadi bagian yang tak terpisahkan dari kehidupan bangsa Indonesia. Untuk itu kita sebagai generasi penerus bangsa harus mampu menjaga nilai - nilai tersebut. Untuk dapat hal tersebut maka perlu adanya berbagai upaya yang didukung oleh seluruh masyarakat Indonesia. Upaya - uapaya tersebut antara lain :

1. Melalui dunia pendidikan, dengan menambahkan mata pelajaran khusus pancasila pada setiap satuan pendidikan bahkan sampai ke perguruan tingg;

2. Lebih memasyarakatkan pancasila;

3. Menerapkan nilai - nilai tersebut dalam kehidupan sehari - hari;

4. Memberikan sanksi kepada pihak - pihak yang melakukan pelanggaran terhadap pancasila;

5. Menolak dengan tegas paham - paham yang bertentangan dengan pancasila. 


\section{BAB III \\ PENUTUP}

\section{A. Kesimpulan}

Berdasarkan hasil penulisan makalah tentang Pancasila Sebagai Pandangan Hidup Bangsa Indonesia, maka penulis dapat menyimpulkan bahwa :

Pancasila merupakan rumusan dan pedoman kehidupan berbangsa dan bernegara bagi seluruh rakyat Indonesia. Apabila nilai-nilai pancasila diamalkan oleh seluruh warga negara Indonesia maka tidak mustahil cita-cita negara Indonesia yaitu mewujudkan masyarakat Indonesia yang adil dan makmur berdasarkan Pancasila dan UUD 1945 dapat terwujud.

\section{B. Saran}

Sehubungan dengan pentingnya pengamalan butir-butir pancasila, maka penulis menyarankan kepada seluruh warga negara Indonesia untuk mengamalkan nilai-nilai luhur pancasila mulai dari diri sendiri dengan kesadaran dan keteladan yang mungkin akan dicontoh oleh orang lain dan menjadi budaya yang positif bagi bangsa Indonesia serta mampu mewujudkan tujuan dan cita-cita bangsa sesuai yang terkandung dalam Pancasila dan UndangUndang Dasar 1945. 


\section{DAFTAR PUSTAKA}

Kansil C.S.T, Pancasila dan Undang-Undang Dasar 1945, Jakarta: PT pradnya paramita.

Pangeran Alhaj S.T.S dan Surya Partia Usman, 1995. Materi Pokok Pendekatan Pancasila. Jakarta; Universitas Terbuka Depdikbud.

Setiady Elly M, Panduan Kuliah Pendidikan Pancasila, Jakarta: PT Gramedia Pustaka Utama.

Srijanto Djarot, Waspodo Eling,dkk. 1994. Tata Negara Sekolah Menengah Umum. Surakarta: PT. Pabelan, UU Nomor 32 Tahun 2003 tentang Sistem Pendidikan Nasioana, Tematik 2016.

Surbakti, K., \& Si, M. (2019). KAJIAN MENGENAI PENTINGNYA BASIS DATA BAGI SEKOLAH SAAT INI. JURNAL CURERE, 2(2).

Surbakti, K. (2018). FOSTERING OF FEMALE PRISONERS IN TANJUNG GUSTA PENITENTIARY OF MEDAN. PROCEEDING: THE DREAM OF MILLENIAL GENERATION TO GROW, 216-225. 